\title{
Being-patient-waiting-for-cardiac-surgery: the preoperative period under the Heideggerian perspective
}

\author{
Ser-paciente-à-espera-da-cirurgia-cardíaca: o período pré-operatório na perspectiva heideggeriana \\ Ser-paciente-a-espera-de-cirugía-cardiaca: el período preoperatorio en la perspectiva heideggeriana
}

\section{Eduardo Tavares Gomes', Regina Célia de Oliveira', Simone Maria Muniz da Silva Bezerra'}

' Universidade de Pernambuco, Nossa Senhora das Graças Nursing School. Recife, Pernambuco, Brazil.

How to cite this article:

Gomes ET, Oliveira RC, Bezerra SMMS. Being-patient-waiting-for-cardiac-surgery: the preoperative period under the Heideggerian perspective. Rev Bras Enferm [Internet]. 2018;71(5):2392-7.

DOI: http://dx.doi.org/10.1590/0034-7167-2017-0506

Submission: 07-24-2017 Approval: 12-09-2017

\begin{abstract}
Objective: to investigate the patients' experience in the cardiac surgery preoperative period under the Heideggerian perspective. Method: exploratory qualitative research. Twelve patients were interviewed, from March to April, 2016, while they waited for myocardial revascularization surgery or valve replacement surgery. Results: the analysis of the speeches allowed finding two dimensions of the being-there-patient-waiting-for-cardiac surgery, two meanings of the beingness: being-there-in-a-reducedworld and being-there-in-a-unknown-world. Conclusion: the experiences were related to alterations and limitations coming from the surgery, potential generators of anxiety, depression and existential conflicts in the cardiac surgery preoperative period. Reinforcing the care as being-with-the-other is suggested, considering the dimensions referred to and the patient's integrality.

Descriptors: Preoperative Period; Cardiac Surgery; Psychological Adaptation; Assistance Humanization; Nursing.
\end{abstract}

\section{RESUMO}

Objetivo: investigar a vivência dos pacientes no período pré-operatório da cirurgia cardíaca na perspectiva heideggeriana. Método: estudo de natureza exploratória, qualitativo. Foram entrevistados doze pacientes, nos meses de abril e março de 2016, enquanto aguardavam cirurgias de revascularização miocárdica ou troca de válvulas. Resultados: a análise das falas facultou o encontro com duas dimensões do ser-aí-paciente-aguardando-cirurgia-cardíaca, dois significados dos existenciais que emergiram: ser-aí-nummundo-reduzido e ser-aí-num-mundo-desconhecido. Conclusão: as vivências estavam relacionadas às mudanças e limitações advindas da cirurgia, potenciais geradoras de ansiedade, depressão e conflitos existenciais no período pré-operatório da cirurgia cardíaca. Sugere-se reforçar o cuidado como ser-com-o-outro, considerando as dimensões referidas e a integralidade do paciente. Descritores: Período Pré-Operatório; Cirurgia Cardíaca; Adaptação Psicológica; Humanização da Assistência; Enfermagem.

\section{RESUMEN}

Objetivo: investigar la vivencia de los pacientes en el período preoperatorio de la cirugía cardíaca en la perspectiva heideggeriana. Método: estudio de naturaleza exploratoria, cualitativa. Se entrevistaron a doce pacientes, en los meses de abril y marzo de 2016, mientras aguardaban cirugías de revascularización miocárdica o cambio de válvulas. Resultados: el análisis de las hablas facilitó el encuentro con dos dimensiones del ser-ahí-paciente-aguardando-cirugía-cardiaca, dos significados de los existenciales que surgieron: ser-ahí-en-un-mundo-reducido y ser-ahí-en-un-mundo-desconocido. Conclusión: las vivencias estaban relacionadas con los cambios y limitaciones provenientes de la cirugía, potenciales generadoras de ansiedad, depresión y conflictos existenciales en el período preoperatorio de la cirugía cardíaca. Se sugiere reforzar el cuidado como ser-con-el-otro, considerando las dimensiones referidas y la integralidad del paciente.

Descriptores: Periodo Preoperatorio; Cirugía Torácica; Adaptación Psicológica; Humanización de la Atención; Enfermería. 


\section{INTRODUCTION}

The proximity of the cardiac surgery brings deep repercussions for those who live such experience. Several thoughts, and restlessness, permeate the patients' minds, who consequently may present signs and symptoms of anxiety and depression ${ }^{(1)}$.

The preoperative stage is marked as a period of great physiological and psychological vulnerability, favoring emotional, humor and, mainly, behavioral unbalance ${ }^{(2)}$. During this period, profound issues and crises arise, varying from guilt and sorrow to more transcendent conflicts, involving the figure of $\operatorname{agod}^{(1,3)}$.

To date, the most studied factors coming from the experience of preoperative period are anxiety, depression and fear (among the patients; families are little considered). These studies reinforce that facing such a stressing fact is not an easy task for patient and family ${ }^{(4)}$. Family, social and spiritual support, among others, is an extremely relevant tool to face stress related to the surgical procedure ${ }^{(5)}$.

It is in this whirl that the nurse acts together with the patient in the preoperative period, and should have the necessary conditions to recognize significant, even subjective, demands ${ }^{(6)}$. Nursing in Brazil has improved its evidence-based assistance, besides having been empowered to promote care guided by a systematization process that uses its own taxonomies and methodologies, improving the assistance practice in the different contexts. In the context of cardiac surgery, there are still few studies that deepen into the core of this experience, subsidizing a more integral, person-centered assistance.

Phenomenological research in the field of nursing, particularly surgical nursing, has the possibility of facilitating the understanding of the patients' experience as an existential phenomenon in an amplified, holistic and profound way, since it seeks to value the uniqueness of the being ${ }^{(7)}$. The German philosopher Martin Heidegger proposes in his ontology a hermeneutics for the understanding of the phenomena that the beings live, the hermeneutics of facticity ${ }^{(8)}$. In a review on anxiety and depression, one has found no articles that used this referential, which allows an in-depth investigation and brings more subsidies to the understanding of this experience, in addition to the traditional quantitative approaches through scales ${ }^{(9)}$.

This study aimed to investigate the patients' experience in the cardiac surgery preoperative period under the Heideggerian perspective. Considering that phenomenology, as a field of research, allows observing phenomena as primary, as provided with a nature of its own, always seeking the essence in existences, putting the experience of the preoperative period under this perspective aims to understand it and go beyond, approaching deeper existential issues for those who experience it ${ }^{(10)}$.

\section{OBJECTIVE}

To investigate the patients' experience in the cardiac surgery preoperative period under the Heideggerian perspective.

\section{METHOD}

\section{Ethical Aspects}

The research was based on the precepts of Resolution CNS 466/2012, evaluated by the Ethics Committee of the HOUC/Procape
Hospital Complex of the University of Pernambuco, and integrated the project approved. After clarifying the contact purpose, the patient was given the possibility of choosing the presence or not of companion during the study. In the case of those who agreed with his/her presence, the companion was informed that should not participate in the answers, issue opinions or express any reaction.

\section{Description, place of study and period}

It is an exploratory qualitative research, with the purpose of analyzing the experience of the preoperative period under the Heideggerian perspective. It was performed in the surgical wards at the Cardiology Emergency Room of the University of Pernambuco, in the months of April and March of 2016.

\section{Population or sample; inclusion and exclusion criteria}

In the phenomenological research, the subjects are considered collaborators, since the researcher understands that he/she does not only deal with people who provide information, but also dialogs with collaborators about the proposed question. Presupposing that the collaborator is the one who can better understand the lived experience, the researcher determines to learn and improve his/her knowledge with him/her(10). Twelve patients who would undergo myocardial revascularization or valve replacement surgery were selected. This phase of the study was done by unintentional sampling, being limited by the theoretical saturation criterion ${ }^{(11)}$. All patients were aware of the surgery and of the procedure date, which would be in up to five days. Selection was made by the following criteria:

- Criteria for inclusion: patients hospitalized in the preoperative period of myocardial revascularization surgery or valve replacement surgery, valve replacement or valve repair surgery, who were aware of the procedure date, scheduled preferably for the following day;

- Criteria for exclusion: decreased level of awareness; impaired verbal communication, or any clinical or psychological condition that would impair the interview or make it uncomfortable; surgical indication for aortic diseases and congenital diseases; previous antidepressant use; prior medical diagnosis of humor, anxiety, or other psychiatric disorders; participation in any protocol of health education or reduction of anxiety; refusal at any stage of the interview.

Although in the phenomenology reference the research planning includes the possibility of new interviews, in order to deepen the knowledge of the preoperative period experience, it was decided for contacting patients whose surgery date was closer.

Considering that the cardiovascular diseases referred to the chosen surgeries are related to life habits and modifiable risk factors, and that this illness may be connected to guilt and other negative feelings, patients with congenital or aortic diseases were excluded because they did not present the same relation ${ }^{(1,3,5)}$. Finally, patients who had experienced health education strategies, which may be a room to relieve tensions and fears, masking the perception of this experience, were excluded.

\section{Study protocol}

The interview was performed after initial approach to the patient, with explanation regarding the purpose of the research and the participation of each one and signature of the Free and Informed Consent Term. 
Initially, a semi-structured interview script was used, which contained a form for the characterization of the subjects (gender, age, income, labor activity, schooling, marital status, number of children and religion) and surgery data (surgery type, hospitalization period, preoperative period, etc.). These data are described in order to show that there was no selection of candidates with particularities that could interfere decisively in the answers.

The interviews began with the research guiding question: how has it been for you to experience the last days of waiting for your heart surgery? In the unfoldment, the dialogue remained with the possibility of other questions being raised by the researchers, in order to get closer to the object of study, leading the interviewee to the heart of the matter ${ }^{(10,12-13)}$.

The interviews took place at the surgical ward, at the bedside, there being only one per day, with an average duration of 21 minutes. They were then transcribed and received the marks of the records that the researchers performed, indicators regarding the condition in which each interview was produced. In the researcher's fieldnotes, the interviewer made registers of non-verbal language that was noticed, which would endorse the discourse and allow preserving the singularities of each individual. The transcript of each interview was performed by the interviewer himself/herself, as soon as possible, with a maximum interval of one week from the interview ${ }^{(12-13)}$.

To preserve privacy and intimacy, as well as respecting the principle of autonomy, patients were asked if they wanted or allowed the presence of the companion in the room, and five interviewees preferred to participate in the study unaccompanied. The companions who remained were instructed not to intervene in any way. The interviews were held in the afternoon shift, after the visiting hours; the morning shift was discarded to avoid interruptions related to the routine of the unit, with the professional routine evaluations ${ }^{(12-13)}$. The transcribed speeches are presented indicating the patients by the letter $\mathrm{P}$ followed by the numbers from 1 to 12 , in order not to allow the identification of the participants.

\section{Analysis of the results}

The analysis of the speeches was based on Martin Heidegger's framework. For the philosopher, the theme of hermeneutic investigation is being-there itself on every occasion ${ }^{(8)}$. In his method, the researcher should seek to understand the meaning or to unveil the meaning contained in the discourse and, for such purpose, it is necessary to have a great involvement of the subjectivity, which guarantees the objectivity. The first step of the method is the discourse. The researcher asks the subject, and the interviewee answers, meaning what was questioned. In the next step, the researcher must devote himself/herself to the material described in order to seek the meaning of the experiences that emerge from the lived reality $(10,12,14)$.

Through facticity, which is the objectivity of the hermeneutics of ontological perspective, the being-there on every occasion is understood, a 'how' of the being in the being, which serves to reveal the essential being-there (Dasein) ${ }^{(8)}$.

A determination of the temporal particularity is the "today - in each case whiling, tarrying for a while, in the present, in each case our own present. Being 'in' the world, being lived 'from out of ' the world"(8). And to investigate the today, Heidegger proposes to interpret the public speech, the way of speaking of oneself, which is born of the way of dealing with the occasion.

In the Heideggerian conception, man is not separated from the world, and the world does not constitute a topographical space, but reflects and understands various ways of relating, living and behaving $^{(10,12,14)}$. In his method there are two main phases: the existential analysis, which is the vague and median understanding, and the extraction of meanings that denote the lived element ${ }^{(12-15)}$. The first phase is based on the expression of the interviewees' experiences, also called privileged entities in their ontic facets. The second phase corresponds to the elaboration of units of meanings, which allow constructing the concept of the lived element. Hermeneutics in Heidegger is represented by the interpretation of the meaning that the being confers on what has been interrogated, denoting the ontological aspect of being-in-the-world ${ }^{(15)}$. In the data analysis phase, the interviewer and another researcher, separately, conducted the steps of the proposed analysis, comparing the results and constructing the dimensions of the lived element from the existential meanings.

The investigators tried to follow these philosopher's clues for understanding the being-there through the facticity, the present, the being-hospitalized, the being-there-patient-awaiting-for-cardiac-surgery.

\section{RESULTS}

The sample consisted of six men (50\%) and six women (50\%), with a mean age of $58.58 \pm 11.8$ years. Most of them were retirees $(10 ; 83.33 \%)$, with a low level of education $(5.5 \pm 5.14$ years of schooling) and average income of 1.83 (1.32) minimum wages (considered at $\mathrm{R} \$ 880$ ). There was predominance of married people $(7 ; 53.8 \%)$, with a mean of $3.2 \pm 2.6$ children. In relation to religiosity, five were catholics (41.7\%) and seven evangelicals (58.3\%).

Regarding surgery, $33.33 \%$ would perform cardiac valve replacement or repair, and $66.67 \%$ would undergo myocardial revascularization. Only one patient $(8.33 \%)$ had already undergone cardiac surgery. The mean time of hospitalization up to the interview was $22.58 \pm 14.39$ days, with an interval of $18.42 \pm 11.86$ days between knowing the surgical decision and the interview.

Questions related to physical signs and symptoms were not mentioned significantly in the answers to the guiding question, and could be placed in the dimension of categories, that is, they are in the world as something that is only in something else and only is, whereas the being-there is in the world in the form of experiences, existing in a world and inhabiting it, staying in it ${ }^{(16)}$.

The analysis of the discourses allowed the encounter with two dimensions of the being-there-patient-awaiting-for-cardiac surgery, analyzing the existential meanings that emerged: beingthere-in-a-reduced-world-and being-there-in-a-unknown-world.

\section{DISCUSSION}

\section{Being-there-in-a-reduced-world}

Being-there-in-the-world presupposes a present and a becoming not understood as future, but as possibility ${ }^{(16)}$.

Prolonged hospitalization waiting for surgery decreases the possibilities for the being-there to express itself as the individual daily structured himself/herself in the world in which he/she 
used to live. Dasein continues to exist in a world in which it suffers if it continues to be requested by the beings to which it was related in daily life ${ }^{(17)}$

We look through the window and see the same thing every day, the cars passing by, and we do not know what it will be, it even cloys me! (P11)

The people stay at that bus stop there [pointing through the window] very early to go to work. You know, even when I retired, I woke up early, before 6:00 AM, to solve my things. Now I wake up early, wait for the breakfast and there is nothing left to do. (P10)

The relation with the reduced physical space of the room refers to the reduction of the world of possibilities and makes reference to the world from which the subject was separated, which spans his doing in the world, and his own existence.

My daughter is who takes care of everything out there; she is even with my credit card! (P7)

It's very difficult to stay here in this room and things to be solved out there! (P3)

For Heidegger, it is through the relationship with the other that the being-there happens, substantially in the care, which can be defined as being-with-the-other. The speech of the caredfor mother reveals the discomfort with this condition ${ }^{(16)}$. Caring expresses itself in being-to-the-other; in the sense that gives meaning to the patients' complaint, who see their lives being lived by others, there is also the difficulty of being-cared-for for those who have developed being-to-the-other ${ }^{(12)}$.

When the patient is replaced in his/her previous environment, he/she may think that is subject to replacement and that he/she is not missed in relationships considered important.

We stay here waiting for someone to tell us what to do. The nurse comes and says there is an examination, other comes and says that there is something else that I do not know what is, the doctor comes and says that there is need to perform another echocardiogram, and also catheterism. They say everything we have to do, and we don't participate in anything; we just have to do and that's it, because we know it is for our good. (P9)

This speech touches the crucial point of autonomy. In the adopted phenomenological perspective, it can be said that for the patient there is a significant conflict between the previous power over his/her life and the dependence on the team's instructions and commands. The patient does not feel empowered or at least important in the conduct of his/her life - although he/ she is hospitalized, his/her life does not cease to be his/her, the domain of the essential being-there. Obviously, it is not a matter of seeing the team as inhumane or of naming it with any other term that characterizes it negatively, but rather of bringing the reflection about settled watch-and-care processes, which can be improved aiming at the being in his/her entirety.

It is very bad indeed [to be hospitalized]. And now it is worse because with this machine [infusion bomb] I cannot stand up.
When it was just saline, I could walk, but it is difficult with this bomb and this swollen foot. They say we have to walk to reduce swelling, but how can I walk? Besides, walking hurts! (P8)

Hospitalization brings impositions on adaptation that not always are well tolerated. Restriction to bed due to fatigue, dyspnea, edema, common signs in heart disease, reduce even more the patient's world - it is only from the ward to the bed. This reduction process, when it is implicit in the therapeutic process, implies denial, rejection or even non-adherence to what is proposed $^{(11)}$. It is common to see disorientated patients pulling away electrodes and care devices as their first option, since which, in a phenomenological perspective, mean reducers of their world, the expression of their being-there and their becoming.

It can still be said that the stress related to the preoperative period is in not attending the beings that demand the patient and that are reasons in the daily life. In the Heideggerian perspective, man does not react to stimuli, but to the motives and requests from the world in which he/she has relationships. The impossibility of attending these motives and requests gives the patient the experience of stress as existential ${ }^{(17)}$.

\section{Being-there-in-a-unknown-world}

The suffering in becoming ill is in the limitation of possibilities and in the difficulty of the being-there to be what it is in essence ${ }^{(18)}$. In this situation, Dasein no longer has the same chances to become-to-be and needs help ${ }^{(17)}$ Heidegger affirms that man is a world-forming, who happens as being-there in the relations and experiences in which he/she manifests himself/ herself in the world, as a form of revelation ${ }^{(18)}$. Man suffers as a being-there-in-the-world and not as having suffering - suffering becomes an existential and a way of being in the world ${ }^{(17)}$.

The individual who undergoes cardiac surgery finds himself/herself restricted in his/her possibilities, mainly due to the ignorance about the process to which he/she is submitted, and which even subjugates him/her.

We think of everything ... The doctor is going to open us, to fiddle inside us, to cut and sew our hearts and we....nothing ... we are almost dead ... and what if it goes wrong? (P6)

I do not know how it is and I don't want to know it. I know that he open us, fix, close and, that's it. After that, there is the ICU. It reminds me Mrs. [...] [a patient who shared the room with the interviewee and who has died during the postoperative period]. She went and did not come back. Sometimes I want to give up, remain this way, as God wishes. But I am here already, what can I do? (P4)

The unknown element of the cardiac surgery, of the postoperative period and of the changes that will affect his/her daily life causes more anguish and fear in the process.

I was never afraid to die, but when Dr. [...] came happy to say that my surgery would be next week, it was weird. She thought I would be happy because I had complained a lot about being almost a month here waiting, but I started thinking about a lot of things ... You know, one month here and I did not think nonsense, but when they said the surgery date, 
I started thinking of a lot of things ... It was the first time I thought that if it went wrong there was no way out, that if it were my time, it was coming. (P1)

I have this way of being, they say that I'm a bit difficult person, but still a bit tough, when I think I'm going to undergo this surgery and I do not even know what's coming, I do not like to think... (P5)

Spirituality is decisive for the patients to deal with the challenging feelings and anxieties that the unknown brings, and they find in it a safe strategy. Spirituality is, in another analysis, openness to possibilities, a world where the uncertain prognosis may not be so dismal and an existential that derives from everyday life, or emerges from the temporal particularity.

If we think about what's going to be, it is worse... It is better to pray and trust that everything is going to be alright, we are going to live and everything is going to be OK. I know so many people that undergo surgery and it works well, why would it work wrong for me? (P2)

I've prayed so much with the rosary that you cannot even imagine! Now, my prayers are up to date because it was a long time without praying. (12)

Sometimes I get sad. Because I know I got here for not taking care of me. I ate everything: fat, salt to taste. My cholesterol level, that stuff we see in blood test, all high levels. Almost diabetic. I even though about changing when I woke up with a pain in my chest, and then I was hospitalized and they said I would undergo a surgery. I did not have time to change, go on a diet. Then I pray, asking God to save me, to let me live, but it was me who caused this situation. (P3)

Most of times, we try to forget the anguish that comes from the suffering, but often the aspiration is for a full restoration in the daily worldliness, where before we always felt at home. For this purpose, we use all the resources available to us ${ }^{(17)}$. From guilt to bargain, from consolation to response to anxieties and restlessness, spirituality is a full possibility for the being-there, contextualized with the occasion, with prior elaboration and with relationships, so that the being-there manifests itself as being-in-the-world.

\section{Study limitations}

As limitation of the study, the lack of triangulation in the data coding phase is indicated, and the results were returned for validation by the own interviewees, since, in order to evaluate the most critical period, patients were interviewed on the eve of the surgery. In addition, although there were minimal interruptions during the interview, there was no exclusive location available for this stage.

\section{Study contributions}

This study reiterates the commitment that nursing has with a humanistic and metaphysical approach, associated with values that refer to the recognition of integrality dimensions in a real moment of care.

\section{CONCLUSION}

This research was the exercise of understanding the other, based on the Heideggerian perspective and having in the phenomenological reduction a tool that made it feasible. In this process, we went from deep reflection on what is manifested by the patient to the attempt to capture and describe what is experienced in the cardiac surgery preoperative period.

The experience of the preoperative period was revealed in a being-there-in-a-reduced world and being-there-in-a-unknownworld, bringing contents that may culminate in existential anguish, potentate humor disorders and psycho-emotional crises. The experiences were related to alterations and limitations coming from the surgery, potential generators of anxiety, depression and existential conflicts in the cardiac surgery preoperative period.

Reinforcing the care as being-with-the-other is suggested, considering the referred to dimensions and the patient's integrality. When using the taxonomies for the systematization of nursing care, it is worth emphasizing the importance of considering the possibility of diagnoses and interventions that are not only related to bio-physiological but also psycho-sociospiritual dimensions.

\section{REFERENCES}

1. Camponogara S, Soares SGA, Silveira M, Viero CM, Barros CS, Cielo C. [Preoperative patients' perceptions of cardiac surgery]. Rev Min Enferm[Internet]. 2012[cited 2017 Apr 17];16(3):382-90. Available from: http://www.reme.org.br/artigo/detalhes/541 Portuguese.

2. Costa VASF, Silva SCR, Lima VCP. [The pre-surgery anxiety of the patient: the alliance between the nurse and psychologist]. Rev SBPH [Internet]. 2010[cited 19 Apr 17];13(2):282-98. Available from: http://pepsic.bvsalud. org/pdf/rsbph/v13n2/v13n2a10.pdf Portuguese.

3. Gomes ET, Espinha DCM, Bezerra SMMS. Religiosidade e crença em Deus no pré-operatório de cirurgia cardíaca: estudo exploratório. O Braz J Nurs[Internet]. 2015[cited 2017 Nov 17];14(3):273-83. Available from: http://www.objnursing.uff.br/index. php/nursing/article/view/5138

4. Gomes ET, Melo RLAS, Vasconcelos EMR, Alencar EM. Use of nursing diagnoses anxiety and fear in the medical and surgical clinics of a university hospital. Rev Pesqui: Cuid Fundam [Internet]. 2012 [cited 2017 Nov 17];4(2):2419-26. Available from: http:// www.seer.unirio.br/index.php/cuidadofundamental/article/view/1779/pdf 575

5. Koerich C, Baggio MA, Erdmann AL, Lanzoni GMM, Higashi GDC. Revascularização miocárdica: estratégias para o enfrentamento 
da doença e do processo cirúrgico. Acta Paul Enferm [Internet]. 2013 [cited 2017 Nov 17];26(1):8-13. Available from: http://www. scielo.br/pdf/ape/v26n1/03.pdf

6. Gonçalves KKN, Silva JI, Gomes ET, Pinheiro LLS, Figueiredo TR, Bezerra SMMS. Anxiety in the preoperative period of heart surgery. Rev Bras Enferm [Internet]. 2016 [cited 13 Nov 17];69(2):374-80. Available from: http://www.scielo.br/pdf/reben/v69n2/00347167-reben-69-02-0397.pdf

7. Oliveira e Silva JM, Lopes RLM, Diniz NMF. Fenomenologia. Rev Bras Enferm[Internet]. 2008[cited 13 Nov 17];61(2):254-7. Available from: http://www.scielo.br/pdf/reben/v61n2/a18v61n2.pdf

8. Heidegger M. Ontologia: hermenêutica da facticidade. 2.ed. Petropólis: Vozes; 2013.

9. Gomes ET, Bezerra SMMS. Ansiedade e depressão no período pré-operatório de cirurgia cardíaca. Rev Rene[Internet]. 2017[cited 2017 Nov 17];18:420-7. Available from: http://www.periodicos.ufc.br/rene/article/view/20078

10. Andrade CC, Holanda AF. Notes on qualitative research and empirical phenomenological research. Estud Psicol[Internet]. 2010[cited 2017 Nov 17];27(2):259-26. Available from: http://www.scielo.br/pdf/estpsi/v27n2/a13v27n2.pdf

11. Fontanella BJB, Luchesi BM, Saidel MGB, Ricas J, Turato ER, Melo DG. Sampling in qualitative research: a proposal for procedures to detect theoretical saturation. Cad Saúde Pública [Internet]. 2011 [cited 2017 Nov 17];27(2):389-94. Available from: http://www. scielo.br/pdf/csp/v27n2/20.pdf

12. González AD, Garanhani ML, Bortoletto MSS, Almeida MJ, Melchior R, Nunes EFPA. Fenomenologia heideggeriana como referencial para estudos sobre formação em saúde. Interface[Internet]. 2012[cited 2017 Nov 15];16(42):809-17. Available from: http://www.scielo.br/pdf/icse/v16n42/aop3612.pdf

13. Paula CC, Padoin SMM, Terra MG, Souza ÍEO, Cabral IE. Modos de condução da entrevista em pesquisa fenomenológica: relato de experiência. Rev Bras Enferm [Internet]. 2014 [cited 2017 Nov 15];67(3):468-72. Available from: http://www.scielo.br/pdf/ reben/v67n3/0034-7167-reben-67-03-0468.pdf

14. Monteiro CFS, Paz EPA, Rocha SS, Souza IEO. Heideggerian Phenomenology and its possibility in the nursing studies constructions. Esc Anna Nery Rev Enferm[Internet]. 2006[cited 2017 Nov 17];10(2):297-300. Available from: http://www.scielo.br/pdf/ean/v10n2/ a18v10n2.pdf

15. Amorim TV, Salimena AMO, Melo MSCS, Souza IEO. Emotions manifested by the being-woman-in-the-world following cardiac surgery. Cogitare Enferm [Internet]. 2013[cited 2017 Nov 17];18(2):268-73. Available from: http://www.revenf.bvs.br/pdf/ce/v18n2/09.pdf

16. Heidegger M. Ser e tempo. Petropólis: Vozes; 2006.

17. Nogueira RP. Estresse e padecimento: uma interpretação de acordo com Heidegger. Interface[Internet]. 2008 [cited 2017 Nov 15];12(25):283-93. Available from: http://www.scielo.br/pdf/icse/v12n25/a05v1225.pdf

18. Heidegger M. Conceitos Fundamentais de Metafísica. Petropólis: Vozes, 2 ed, 2012 